DOI: https://doi.org/10.32839/2304-5809/2021-11-99-18

УДК 821.161 .2

Яковлева I.B.

Інститут фрілології Київського університету імені Бориса Грінченка

\title{
ОСОБЛИВОСТІ ГЕНДЕРНОЇ ПСИХОЛОГІЇ ЖІНОЧИХ ОБРАЗІВ У «НАРОДНИХ» ОПОВІДАННЯХ МАРІЇ ГРІНЧЕНКО
}

Анотація. У статті здійснено аналіз гендерної психології персонажів оповідань «для народного читання» Марії Грінченко (Загірньої) на матеріалі неопублікованих оповідань «Зароблене щастя», «Наплакалась я сьогодні..." та ін. Гендерний підхід використано з метою доповнення традиційної інтерпретації творчості письменниці розкриттям особливостей підходу до зображення внутрішнього світу персонажів, обумовлених впливом біографічних чинників на процеси художнього осмислення авторкою фрактичного матеріалу. Для аналізу обрано неопубліковані оповідання, оскільки вивчення автографрів дає можливість простежити етапи створення тексту, водночас найповніше відбиваючи індивідуальні особливості писемного мовлення авторки. Як саме відбувалася спільна творча праця Марії Грінченко з їі видатним чоловіком Борисом Грінченком, інші подробищі становлення української письменниці, дізнаємося з цих і подібних джерел. Встановлено, що оповідання зокрема піднімають теми тогочасного становища жінки в селянській общині.

Ключові слова: Марія Грінченко, Марія Загірня, Борис Грінченко, гендер, гендерна інтерпретація, гендерна психологія персонажів, психоаналіз.

Yakovleva Iryna Institute of Philology of Borys Grinchenko Kyiv University

\section{GENDER-TERM PSYCHOLOGY FEATURES OF WOMEN'S IMAGES IN MARIA GRINCHENKO'S "FOLK" STORIES}

Summary. In the article the gender-term psychology of Maria Grinchenko's (pen name - Maria Zagirnia) stories "for public reading" are analyzed. The analysis based on the previously unpublished novels "Zaroblene shchastia" ("Earned happiness"), "Naplakalas ya sohodni..." ("I cried today...") and other materials. The analysis is carried out in a comparative aspect. The gender approach is used to supplement the traditional interpretation of the Maria Grinchenko's works by disclosing other levels of creation its women's images. The article makes an attempt to explore the features of Maria Grinchenko's creative evolution as an aesthetically reflection of her life story. These unpublished stories were chosen for analyzing because of need to include it into scientific circulation as unfairly forgotten. At the same time elected autographic texts shows us, that newly discovered archival documents may be used to complete and clarify various aspects of Ukrainian intelligent families activity in the global context of the Ukrainian literary process at the end of XIX - beginning of the XX century. The article investigates these documents and some other materials to reveal the main points Maria Grinchenko's cooperation with Boris Grinchenko. It hightlights relationship between both parts of Grinchenko's family and their mutual influence while their work as partners for the goals of national education and modernizing Ukrainian culture. It is established that we can call these materials of Grinchenko's family creative and documentary heritage a valuable sourse for understanding Maria Grinchenko's evolution as a writer. In addition, Maria Grinchenko theoretically interpreted the treatment of a woman in Ukrainian society due to the "women's question". The hypothesis about these views as criterion of choosing themes of stories is put forward. Analyzed works presents the importance of performing the traditional for married couples' roles of the Husband and Wife, understanding of the complexity of the process of formation of these images-archetypes, as well as their awareness in the described social conditions.

Keywords: Maria Grinchenko, Maria Zagirnia, Boris Grinchenko, gender, gender interpretation, gender psychology of characters, psychoanalysis, archetypes.

Постановка проблеми. У численних спо1 гадах, залишених сучасниками про родину Грінченків, Марія Грінченко постає втіленням класичного зразка жінки як дружини і матері, "вірнил товаришел у всіх заходах $i$ в багатьох важних $і$ важких праиях" - товаришем, що і на сьогоднішній день залишається в тіні свого чоловіка [8, с. 213].

Марія Грінченко - «дружина одного з найвизначніших наших письленників $і$ діячів Бориса Грінченка", яка, "вийшовши заліж, широ перейнялася ідеяли свого чоловіка" [8, с. 213] і "стала полічницею $і$ співробітницею в усіх літературних, гроладських, видавничих та наукових справах» [10; 13]. До такого традиційного бачення постаті Марії Грінченко як талановитої, але «половини» Бориса Дмитровича значною мірою причетна і вона сама, бо, залишивши чимало спогадів про свого чоловіка, свій вклад у його подвижницьку працю зазвичай скромно замовчувала, залишаючись у тіні авторитетної постаті видатного просвітника, i, за словами сучасників, не виказуючи себе «нічил, крім честі бути дружиною Бориса Грінченка» [12].

Аналіз останніх досліджень і публікацій. Просвітницьку та літературну діяльність М. Грінченко досліджували її сучасники Д. Дорошенко, С. Єфремов, С. Русова; на сьогодні наявні два дисертаційні дослідження біографії та творчості - «Літературно-мистецькі та наукові пошуки Марії Загірньої» Л. Неживої (2001) та «Педагогічна та просвітницька діяльність Марії Грінченко» М. Лашка (2017).

Виділення не вирішених раніше частин загальної проблеми. Оскільки більшість творів подружжя Грінченків були написані 3 праг- 
матичною, часто виховною метою, часто основними темами оповідань та повістей ставали також сімейна та соціальна проблематика.

Ретельно задокументовані подробиці літературної діяльності та повсякдення обох Грінченків відомі зокрема й завдяки М. Грінченко, яка не тільки описала їх у численних спогадах, а й залишила власні коментарі подій.

Застосування ж до творів Бориса та Марії Грінченків гендерний підхід дозволяе багато в чому доповнити традиційне прочитання.

Метою статті $€$ аналіз гендерної психології персонажів оповідань «для народного читання» Марії Грінченко (Загірньої) на матеріалі неопублікованих оповідань «Зароблене щастя», «Наплакалась я сьогодні...» та ін., що дає можливість розглянути подробиці становлення Марії Грінченко як письменниці, а також особливості художнього осмислення авторкою фрактичного матеріалу.

Актуальність дослідження зумовлена потребою застосування нових підходів задля належної оцінки культурної вартості творчості М. М. Грінченко, яка й досі залишаються маловивченою, а іноді й незаслужено забутою тінню свого безумовно видатного чоловіка Б. Д. Грінченка.

Виклад основного матеріалу. Марія Грінченко (псевдо Марія Загірня) зазвичай згадується дослідниками як письменниця, що стала такою винятково під впливом свого видатного чоловіка. Дійсно, сама М. Грінченко була невисокої думки про власні здібності й зізнавалася, що "...не звикла сама без Борисової поради праиювати» [3]. Мабуть із ціеї причини вона й залишилася в українській літературі авторкою творів для дітей і кількох оповідань 3 народного життя.

Проте її літературний талант належно оцінювали сучасники.

Так, Ганна Барвінок у листі Борисові Грінченку, докоряючи жінкам-письменницям за відсутність нових творів, пише: "...Ваша дружина як владіє перол - $i$ не хоче однієї сльозини проронить..." [11, с. 86].

Навіть зважаючи на розвінчану уже теорію про те, що жінка-письменниця могла сформуватися виключно під чиїмось впливом, аналізувати творчість Марії Грінченко окремо від Бориса Грінченка неможливо, бо в їі випадку це твердження істинне. Принаймні, якщо зважати на її власну думку.

Не можна, в свою чергу, й відмовлятися вважати М. Грінченко самостійною фрігурою культурного простору, стверджуючи, що вона лише допомагала чоловікові, виконуючи технічну роботу. Рукописи дозволяють простежити шлях становлення Марії Грінченко з етнічної росіянки і вчительки Гладіліной, яка щиро "обрусяла украӥнських діточок, бо вважала, шо російська мова несе їл культурун [9], до видатної письменниці та просвітниці М. Загірньої, глибоко обізнаної в усіх тонкощах видавничої діяльності. Розглянемо період вчителювання Грінченків у селі Олексіївка (1887-1893 рр.) дає найбільше матеріалу для дослідження іхньої творчості. Саме в Олексіївці молоде подружжя ретельно досліджувало смаки і потреби читача 3 народу та займалося виданням дешевих книжечок-метеликів для народного читання.
Подробищі дізнаємося зі спогадів, листів, інших архівних документів.

Зокрема з листування Б. Грінченка з А. Кримським, де А. Кримський у листі від 23 лютого 1892 р. відповідає на питання, які саме твори були б “ходовими» для розповсюдження серед селян: "Губанов [видавець] навпрялещь каже, шо найкраше підійдуть задля видання книжки $з$ сюжетол любовнил" [7].

I в наступному листі ще раз наголошуе: "Губанов хваливсь, що заловив однолу "купчине" повість на мішаній мові, але під "дуже гарнил заголовкол" - "Нешасне кохання»! "От коли б Ви писали шось таке, - додав він, - то ие дуже гарно було б!» [7]. На що Б. Грінченко відповів 6 квітня 1892 р.: "Спробую може вшкварити [Є.] Губ[анову] яке "Найнешасливіше кохання" хоча не ручуся" [7].

У 1892 р. Б. Грінченко починає публікувати в часописі «Зоря» перші частини дослідження читацьких смаків під назвою «Українська книжка на селі», де $є$ зауваження, що сільська молодь любить читати «про хлопців та дівчат».

Матеріал, названий «першил у нашолу літературознавстві дослідженнял соціологї̈ народного читання" [9, с. 86], обгрунтовуе теоретично принципи творення Грінченками художніх текстів і не втрачає своєї актуальності й досі.

Зразковими для народного читання й такими, що знаходять жвавий відгук у слухачів, названі оповідання «співця жіночого горя» Марка Вовчка.

Промовистим 3 огляду на причини, що могли стати поштовхом для написання оповідань «жіночого горя», є зокрема епізод читання «Iнститутки» й коментарі присутніх про фрізичне насильство, себто "карання жінок», де автор зауважуе, що говорять про це самі жінки. Записи таких, «здебільшого сумних» оповідей, вочевидь лягли в основу наявних в архівах рукописних замальовок.

Вони свідчать і про спроби писати подібні твори, але з тих чи інших причин більшість залишилися тільки у вигляді чернеток. Серед них знаходимо й перші проби пера М. Грінченко, яка в усьому підтримувала чоловіка. Нижче робимо спробу аналізу структурної організації змісту текстів оповідань з позиції гендерної психології, що дає можливість розглянути їх у психоаналітичній інтерпретації та розкрити на новому рівні значення смислового наповнення.

Розглянемо «народні» оповідання, що піднімають теми становища жінки - «Зароблене щастя» (1890), «Наплакалась я сьогодні...» (1893) та ін.

Для аналізу використаємо алгоритм, розроблений Н. Зборовською на основі методологічних набутків 3. Фройда, К.-Г. Юнга, Ж. Лакана та ін., що вже використовувався нами для аналізу творів Б. Грінченка тіеї ж тематики [6].

Стилістика оповідань, як було сказано вище, заснована на дослідженні читацького сприйняття творів Марка Вовчка, також етнічної росіянки та постаті, суперечливої для широкого загалу й досі. Б. та М. Грінченки у написаному спільно біографічному нарисі про Опанаса Марковича, зокрема висловлювали сумнів, що Марко Вовчок могла самостійно написати свої «Народні оповідання». 
Проте написана 26 квітня 1892 р. і опублікована у львівській «Зорі» заява-протест проти образи Оленою Пчілкою Марка Вовчка є свідченням того, що тема самостійності жінки-авторки для подружжя Грінченків була важливою та глибоко особистою. Адже Грінченки вважали вкрай необхідним донести до широкого загалу власну позицію: називати жінку "...за те, що вона, ідучи слідом за свойм чоловіком, написала вкупі з ӥм відомі українські твори <...> "нахабною кацапкою", се значить кидати на людину незаробленою образою і виявляти тил невдячність до неї» [5]. Так само, як і у випадку Грінченків, "...невідомо досі, скільки власне праці клала д-ка Марія Марковичка на ті твори, а скільки Опанас Маркович. Певна тільки річ, що була в тих творах $і$ їі така чи инша частка та що ті твори посунули наперед українську літературу" [там же].

Дослідження рукописів Марії Грінченко періоду перших самостійних проб пера вважаємо доцільним з огляду на можливість висвітлити невідомі раніше деталі такого співавторства. Дослідники зазначають, що ступінь втручання Бориса Грінченка у рукопис залежав від тематики найбільше редагувалися науково-пізнавальні тексти, майже незмінними залишалися вірші [9]

Архівні матеріали розкривають подробиці процесу творення й текстів окресленої нами вище тематики, з яких бачимо, наскільки відповідальним було ставлення обох (спів)авторів до зовні простих і дещо наївних оповідок.

Так, рукопис незавершеного оповідання «Зароблене щастя" (1890) дозволяе простежити, як саме відбувалася співпраця Бориса та Марії Грінченків завдяки поміткам і виправленням в тексті.

За сюжетом неопубліковане оповідання нагадуе відому повість Г. Квітки-Основ’ненка «Козир-дівка». Молодого коваля Карпа обвинувачують у крадіжці (частина I), а закохана в нього дівчина Оксана знаходить спосіб добитися до нього у в'язницю (частина II) та зрештою визволити (частина III).

Суттево відрізняеться поведінка героїні лише іще більшою, ніж у Квітчиній повісті, наївністю адже Оксана не знайшла нічого кращого, аніж самій сісти у в'язницю за обвинуваченням у крадіжці. Звернімо увагу на важливі для логіки викладу деталі, що вказують на загальноприйняті в традиційній культурі норми поведінки. Наприклад, початок частини II: «Страшна звістка про те, шо Карпа узято у острог, дійшла й до його дівчини Оксани. Ї̈ страшно вразило ие. Ї̈ вразила велика кривда, що зроблено ї̈ милому <...> Ïй хотілось бігти до Карпа і сказати йому, щоб він не думав так, що вона вірить йому, любить його білш, ніж любила. Але вона не бігла..." [1]. Дивний вчинок героїні задля побачення 3 коханим виглядає обгрунтованим, адже йому передуе розлогий опис її почуттів і роздумів над способами отримати бажане.

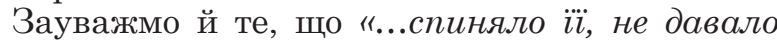
̈̈й ити у острог, бо як же вона балакатиле тали при людях» [там же]. Тобто Оксанин вчинок обумовлений не лише її незрілістю та наївністю, а й необхідністю гендерно-нормативної поведінки, що передбачае стриманість і приховування почуттів від сторонніх.

Далі в тексті викреслено речення, що описують емоційний стан Оксани.
Про те, що текст планувалося вдосконалити, свідчать типові для більшості рукописів авторки примітки. Досить часто Борис Грінченко переробляв початок, тож на полях описаного абзацу бачимо пораду: "Краще хай буде росповідано, що люде помічали за Оксаною» [там же]. I ще коментар, спрямований на посилення драматизму викладу: «Треба инакше: хай люде думають, що Оксана справді хотіла вкрасти, хай злучать ї̈ вчинок з обвинуваченням проти Карпа» [там же].

Варто зазначити, що М. Грінченко часто заздалегідь залишала для доопрацювання чоловікові частини тексту й очікувала його допомоги.

Частина III фактично не має початку, крім: "Оксана опинилась у острозі, у толу сале остpозi, де був i Kарпо. Їй хотілося побачити його» [там же].

Розв'язка, описана простою народною мовою i, вочевидь, природня для сприйняття при читанні вголос, украй нелогічна. Адже добрий слідствуватель, який розібрався у справі, аж ніяк не взятий авторкою з реальності, яку вона могла спостерігати під час вчителювання. Проте 3 точки зору психології особливістю цього оповідання $е$ саме наївність героїні, яку обом Грінченкам доводилося неодноразово спостерігати, працюючи серед селян. Не очевидним для сучасного читача може бути психологічний розвиток героїні, покладений в основу сюжету:

- Оксана не наважуеться поговорити з коханим при сторонніх;

- розмова зі слідствувателем, завдяки якій Оксана знаходить у собі сили не зважати на соціум і традицію: "- А слава яка тепер про мене, а поговір? Йому тоді од людей просвітку не буде через мене. - Що люде? Хиба ти зважала на людей, як ишла рубати Божкову скриню?»

- розв'язка: "....того вечора сиділи Карпо з Оксаною в садку" [там же].

Сюжет підсумовуе частину останнього речення - дівчина "заробила собі право сидіти вдвох", незважаючи на поголос, тобто неприйнятність такої «розкутої» з боку дівчини поведінки в традиційному суспільстві.

Остання ж ремарка про батьків, які «не йшли кликати Оксану у хату", бо зрозуміли та прийняли її вибір, ще раз підкреслюе призначення твору для народного читання - спонукати замислитися над недоліками суспільства.

Оповідання «Наплакалась я сьогодні...» М. Грінченко також показове з точки зору психології жіночих персонажів, головного та другорядних [2].

При цьому варто відзначити традиційність (звичаевість) як основу жіночого життя в сім'ї та суспільстві, що покладено в основу сюжету.

Виклад оповіді емоційно забарвлений, ведеться від першої особи - особи головної героїні Насті, яка по мірі розгортання сюжету асоціюеться із жіночим архетипом Дівчини (Дитини): нерозважливої, незрілої та надто емоційної.

Можна 3 упевненістю стверджувати це 3 тієї причини, що дії героїні засновані не стільки на власному виборі та думщі, а на наслідуванні звичаю, який пронизуе все оповідання: Дівчина стає Жінкою, виходячи заміж, і отримуючи необхідний особистісний досвід та «дорослі» жіночі обов'язки.

Говорячи про остаточне формування особистості за таких умов, а саме - за умови шлюбу 
(мова навіть не йде про шлюб через почуття), можна припустити, що процес так і не завершуеться повністю. Тому персонажі, які на початку асоціюються 3 жіночим архетипом Дівчини, залишаються в цьому ж психологічному стані і після розв'язки. Розкриваючи психологічний розвиток головної героїні і підкреслюючи її співвіднесеність із жіночим архетипом Дівчини, слід відзначити основні події оповіді:

1. Взаємні почуття із Миколою, від якого Настя чекае старостів;

2. Від’ізд Миколи і довіра до подруг, які із заздрості та відсутності власного досвіду обмовляють Миколу, який нібито насміхався з Насті; тут варто відзначити, що сама Настя у прагненні зберегти стосунки з Миколою в таємниці кілька разів досить нетактовно говорить про ставлення до нього подругам:

- А з коханнал своїл ховалася, було при других дівчатах неначе $i$ нелає між нал нічого. Звичайно, дівчата догадуюиия, допитуюиия, що було в лене, а я аж сердюся неначе, шо вони міні про Миколу кажуть.

- Одчепіция, кажу, геть із вашил Миколою, дуже міні його треба [там же].

В можливість аналогічної ситуації для Миколи дівчина не вірить, через що повністю підпадає під уплив подруг, що знов свідчить про її незрілість;

3. Готовність до «принизливого» шлюбу не може зупинити навіть розмова із Миколою; неспроможність заплатити «за бесчестя» відкупного;

4. Відсутність боротьби і в подальшому - прийняття фракту одруження Миколи, фрізичного насильства 3 боку чоловіка у власному шлюбі також не сприймаються як психологічне дозрівання: скоріше, як нове примирення із ситуацією, тобто досить дитяча поведінка, притаманна боязкій Дівчині;
5. Спогад про останню відверту розмову з Миколою, який запевняє, що, як і раніше, має до неї почуття, незважаючи на появу дружини.

Отже, трансформація головної героїні у психологічно зрілий жіночий образ так і не відбувається.

Описуючи становище сучасниці-жінки в традиційному суспільстві без жодних способів та сил для боротьби із ситуацією, авторка має на меті викликати внутрішній супротив, бажання змінювати життя суспільства.

Як і в Б. Грінченка, зосередженість М. Грінченко на змалюванні «нового героя» $\mathrm{i}$ «нової особистості» дозоляе говорити і про вплив суспільного ладу на слабших героїв, і про готовність до змін - у більш сильних, і про необхідність осмислення впливу суспільних процесів для особистості в цілому. При цьму виокремлення відмінностей у цих процесах на прикладі персонажів Бориса Дмитровича та Марії Миколаївни не вважаємо доцільним, адже їм притаманна велика кількість спільних психологічних рис, основою з яких постає готовність або неготовність персонажа до протистояння із обставинами та звичаєм, бажання або небажання робити життевий вибір, у чому, зокрема, і проявляється гендерна психологія персонажів, ступінь їх зрілості та осягнення власного «я».

Висновки. Перебіг сюжету і характери персонажів у творах Бориса Дмитровича та Марії Миколаївни Грінченко є закономірним та необхідним наслідком психологічного розвитку героїв та набуття ними суспільного, освітнього та особистісного досвіду в цілому. Також у текстах підкреслено важливість виконання обумовлених традицією ролей захисника та берегині в сім'ї, розуміння авторкою складності процесів становлення та відтворення цих образів-архетипів, а також спроби дати поштовх осмисленню ролей Чоловіка і Дружини в описаних соціальних умовах і відповідним змінам у їх сприйнятті.

\section{Список літератури:}

1. Грінченко М. Зароблене щастя. Інститут рукопису Національної бібліотеки Украӥни іл. В. I. Вернадського. Ф. I. Загальний. Спр. 32393.

2. Грінченко М. Наплакалась я сьогодні... Iнститут рукопису Національної бібліотеки Украйни ілм. В. I. Вернадського. Ф. І. Загальний. Спр. 32397.

3. Грінченко М. Як я шукала роботу... Інститут рукопису Національної бібліотеки України іл. В. I. Вернадського. Ф. І. Загальний. Спр. 32543.

4. Загірня М. Спогади / передмова, упоряд., приміт. Неживої Л. Луганськ : Шлях, 1999. С. 27-85.

5. Заява [Протест проти образи Оленою Пчілкою Марка Вовчка]. Зоря. 1892. № 11. С. 220.

6. Зборовська Н. Психоаналіз і літературознавство : Посібник. Київ : «Академвидав», 2003. 392 с.

7. Кримський А. Твори : у 5 т. / редкол.: І. Білодід (голова) [та ін.]. Т. V, кн. 1. Київ : Наук. думка, 1973. С. $42-45$.

8. Луговий О. Визначне жіноцтво України: Історичні життеписи. Київ : Дніпро, 1994. 336 с.

9. Нежива Л. Марія Загірня: Літературний портрет : монографрія. Луганськ : Знання, 2003. 170 с.

10. Неживий О., Нежива Л. На ниві добротворення (До 135-річчя з дня народження Марії Загірньої). Дивослово. 1998. № 6. C. 13-15.

11. Олещенко Т. Право на першість. Літературний процес: методологія, ілена, тенденцї. 2017 . № 10. С. $84-87$.

12. Русова С. Наші визначні жінки: літературні характеристики-силюети. Коломия : [б. в.], 1934.92 с.

\section{References:}

1. Hrinchenko, M. Zaroblene shchastia [Earned happiness] (Fund 1 Zahalnyi. File 32393). Institute of Manuscripts of National Library of Ukraine named after. V. I. Vernadsky. Kyiv. (in Ukrainian)

2. Hrinchenko, M. Naplakalas ya sohodni... [I cried today...] (Fund 1 Zahalnyi. File 32397). Institute of Manuscripts of National Library of Ukraine named after. V. I. Vernadsky. Kyiv. (in Ukrainian)

3. Hrinchenko, M. Yak ya shukala robotu... [How I was looking for a job...] (Fund 1 Zahalnyi. File 32543). Institute of Manuscripts of National Library of Ukraine named after. V. I. Vernadsky. Kyiv. (in Ukrainian)

4. Zahirnia, M. (1999) Spohady [Memoirs]. Luhansk: Shliakh, pp. 27-85.

5. Zaiava [Protest proty obrazy Olenoiu Pchilkoiu Marka Vovchka] [Statement [Protest against the insult of Olena Pchilka by Mark Vovchko]. Zoria, 1892. Issue 11, p. 22. (in Ukrainian)

6. Zborovska, N. (2003) Psykhoanaliz $i$ literaturoznavstvo [Psychoanalysis and literary criticism]. Kyiv: "Akademvydav», 392 p. (in Ukrainian) 
7. Krymskyi, A. (1974) Tvory [Collected works in 5 vol.]. (Vol. 5, book 1). Kyiv: Naukova dumka, pp. $42-45$. (in Ukrainian)

8. Luhovyi, O. (1994) Vyznachne zhinotstvo Ukrainy: Istorychni zhyttiepysy [Outstanding Femininity of Ukraine: Historical Biographies]. Kyiv: Dnipro.

9. Nezhyva, L. (2003). Maria Zahirnia: Literaturnyi portret [Mary Zagirnia: Literary portrait]. Luhansk: Znannia, 170 p. (in Ukrainian)

10. Nezhyvyi, O., Nezhyva, L. (1998) Na nyvi dobrotvorennia (Do 135-richchia z dnia narodzhennia Marii Zahirnoi) [In the field of charity (To the 135th anniversary of the birth of Maria Zagirnaya)]. Dyvoslovo, 6, pp. 13-15.

11. Oleshchenko, T. (2017) Pravo na pershist [The right for primacy]. Literaturnyi protses: metodolohiia, imena, tendentsii [Literary process: methodology, names, trends], issue 10, pp. 84-87.

12. Rusova, S. (1934). Nashi vyznachni zhinky: literaturni kharakterystyky-syliuety [Our Distinguished Women: literary characteristics]. Kolomyia: [n. p.], 92 p. 